NBER WORKING PAPER SERIES

\title{
THE EMERGENCE OF STRONG PROPERTY RIGHTS: SPECULATIONS FROM HISTORY
}

\author{
Raghuram G. Rajan \\ Luigi Zingales \\ Working Paper 9478 \\ http://www.nber.org/papers/w9478 \\ NATIONAL BUREAU OF ECONOMIC RESEARCH \\ 1050 Massachusetts Avenue \\ Cambridge, MA 02138 \\ January 2003
}

This paper has benefited tremendously from comments by Candice Prendergast. It is partly based on work with Abhijit Banerjee. Much of this working paper is forthcoming as chapter 6 of Saving Capitalism from the Capitalists (Crown Business, Random House). The views expressed herein are those of the authors and not necessarily those of the National Bureau of Economic Research.

(C2003 by Raghuram G. Rajan and Luigi Zingales. All rights reserved. Short sections of text not to exceed two paragraphs, may be quoted without explicit permission provided that full credit including notice, is given to the source. 
The Emergence of Strong Property Rights: Speculations from History

Raghuram G. Rajan and Luigi Zingales

NBER Working Paper No. 9478

January 2003

JEL No. D23, D72

\section{$\underline{\text { ABSTRACT }}$}

How did citizens acquire rights protecting their property from the depredations of the government?

In this paper, we argue that one important factor strengthening respect for property is how it is distributed. When there is some specificity associated with property, and property is held by those who are most productive, the distribution of property becomes relatively easy to defend. By contrast, when property is owned by those who get rents simply by virtue of ownership, the distribution of property becomes much harder to defend. We speculate on why some countries have been able to develop a climate of respect for property rights while others have not.

Raghuram G. Rajan

Graduate School of Business

University of Chicago

1101 East $58^{\text {th }}$ Street

Chicago, IL 60637

and NBER

raghuram.rajan@gsb.uchicago.edu
Luigi Zingales

Graduate School of Business

University of Chicago

1101 East $58^{\text {th }}$ Street

Chicago, IL 60637

and NBER

luigi.zingales@gsb.uchicago.edu 
A sine qua non for almost any institution of capitalism to work is that the property of each citizen be respected. This means more than simply allowing and enforcing each individual's right to own private property: It also means respecting the rule of law more broadly by facilitating and enforcing private contracts, preventing arbitrary coercion, and preventing arbitrary taxation.

The critical element in ensuring security of property in most countries today is not how covetous other citizens are - a strong government can always beat down the greedy. It is not even how rapacious foreign invaders are - warfare in recent times has not typically been conducted for the express purpose of pillaging the property of enemy citizens. The critical element in ensuring security of property has been the commitment of a country's government to respect the property rights of its own citizens.

Some countries have come a long way. The United States or the United Kingdom, models of rectitude in their respect for property today, routinely expropriated wealthy creditors in the past. Others are less respectful today than in the past, suggesting that governments do not have permanent sinecures on their ability to commit to respect their citizens' property. Despite Rome being the cradle of law, and Venice the source of much innovation historically in business contracting, Italy today lags considerably behind some of its northern neighbors in measures of respect for the rule of law and respect for property. So if it is not something immutable in a people's culture or psyche that causes them collectively to agree to respect property, what is it? Should citizens in developed countries be worried about whether their governments will continue to respect property? We seek an answer in this paper. 


\section{The Main Argument}

A property right is a form of monopoly. It gives the owner of an asset the exclusive right to use the asset and exclude others from its use. But what gives the owner this right? We might be tempted to answer: "The Law". While it is true that in modern developed societies, property rights are enforced by the legal system, this answer begs the question of what gives the law force. Why in certain countries is the law respected and enforced, even against the might of the government, while in others it is not?

One possible explanation is the nature of the government. Some have argued that by constitutionally enhancing the "countervailing" power of parliament and the judiciary, a government can offer a credible commitment to not expropriate its citizens. ${ }^{\mathrm{i}}$ There is, however, something incomplete in the argument that the government can show its commitment to respect property by setting up a more democratic political process, which keeps the arbitrary powers of the government in check. At the national level, most rules can be changed. The government can dispense with the democratic political process. Political power is therefore not easily conferred by legislative fiat or a change in the constitution. It is more fruitful to think of the devolution of political power and the security of property not as a political or legal phenomenon alone, but partly as an economic phenomenon. This is the approach we take.

To do so we need to go back in time, when legal enforcement was doubtful even in countries where property is now well respected, and understand, step by step, how basic respect for property emerged. To root ourselves firmly in facts, we will examine how England moved in little over a hundred years from being a state under an arbitrary despot to being ruled by a constitutional monarchy. Before we do so, however, it is useful to preview the logic of our argument. 
A property right is much more defensible when the owner manages the property much better than anyone else. There is a substantial cost to taking the property away, for the owner's skills would no longer be available - certainly to the extent it was earlier -- for generating value with the property. Thus property that is owned by those who can manage it best is property that not only has the law to support it, but also has economic value backing it. To the extent that the government respects economic value, either because of the power it can purchase, or the taxes it can pay, an economically efficient distribution of ownership is much more secure than a distribution based on the accident of history or on the whims of the king. ${ }^{\text {ii }}$

A political institution like parliament is not irrelevant here. To the extent that owners are dispersed, parliament can help them gather and coordinate their actions. But democratic institutions are an instrument, not the source, of their power. This is not just a matter of semantics. With the "wrong" distribution of property, a country will find it very hard to achieve the right balance between the power of the government and the power of the people, no matter how many democratic institutions it has.

At this point all this may seem just conjecture, but we will now substantiate it. We will examine why respect for property rights emerged when it did in England and why it took so long for other countries to follow England's footsteps. While mainly historical, our analysis is relevant today, not just for countries like Russia that are attempting to establish secure property rights for their citizens, but also for countries where property is secure today, so that its continued security can be assured.

\section{The Rapacious Government}

Security of property started with protection from foreign invaders. The generalized improvement in standards of living, which occurred in Western Europe from the beginning of the 
second millennium, is attributable, at least in part, to the security of its Eastern borders, which lead to the end of the Barbarian invasions. Thus, military security is an important element of economic and financial development. But it is not sufficient. Nor is it true that more military security is always better for finance. In fact, within Western Europe, the cities that emerged as the most important financial centers (first Florence, Genoa, and Venice, then Hamburg and the cities of the Hanseatic League) were not the political capitals of the then military superpowers, but independent political entities, very much exposed, with the possible exception of Venice, to the risk of foreign invasions. Why did they succeed where Paris, Vienna and Madrid did not?

A nation's military might does not necessarily translate into a sense of economic security for the citizens. In fact, through much of history it has been quite the opposite. The stronger is a government's military power, the greater is its need for funds to feed and pay its soldiers, and the stronger is its temptation to simply take from its own citizens (especially if even-more-temptingalien-citizens are not at hand). History is rife with examples of how the rich attracted the unwanted attentions of their own powerful monarch. The fate of the Templars in the early fourteenth century offers a salutary warning of what happened when a needy king went up against his citizens, no matter how morally and physically powerful they might be.

The Military Order of the Knights of the Temple of Solomon, better known as the Knights Templars were the first significant international bankers. They were recruited largely from the younger sons of nobility who stood no chance of inheriting titles or wealth. They devoted themselves to the Church, and initially lived near the ruins of the Temple of Solomon in Jerusalem, from which they took their name. They took upon themselves the duty of policing the highways used by pilgrims going to Jerusalem. Their lives were chaste and austere, and they 
reserved their passion for warfare. Because they apparently did not fear death, they were among the most feared warriors on earth. iii $^{\text {in }}$

As a result of gifts from the grateful and the faithful, they grew in wealth. They came to own some of the strongest castles in the world. Given their military prowess, these served as ideal repositories for valuables in those troubled times. King John of England used the London Temple as a repository for the crown jewels, and in 1261, his son Henry III, who was in trouble with his nobles, felt they would be safer if transferred to the Templar fortress in Paris. ${ }^{\text {iv }}$

These castles formed a network of "branch offices" which meant they could make cash available at both ends of the Mediterranean, as well as in Paris or London, when needed and in the form that was locally accepted. ${ }^{\mathrm{v}}$ A knight could deposit money in Paris and receive it in the appropriate currency in Jerusalem. Crusading knights used this network, the American Express of the Crusades, to keep themselves in funds as they traveled. Of course, the Templars charged a fee both for the exchange and the transfer. Local banking functions were also performed. A number of surviving parchments suggest that the Temple in Paris operated what looks like a modern bank's cash desk, open at pre-specified times, and allowing clients to deposit and withdraw money. Clients appeared to be a Who is Who of the time, and included the Royal family, important Church officials, nobles, and rich merchants. ${ }^{\mathrm{vi}}$

The Templars' financial functions soon rivaled or exceeded their military functions. They were trustees for Crusaders and administered their wills, they acted as revenue agents for various monarchs and popes, and they served as financial advisers for the rich and powerful.

Substantial amounts of money were in Templar vaults at any point in time. Unfortunately, while their castles were strong, they were no match for a determined sovereign. In 1263, during the conflict with Simon of Montfort, Prince Edward of England overcame Templar 
opposition to enter its treasury. He broke into strong boxes, and seized money belonging to a number of barons and merchants. His son, Edward II, did a similar thing on his father's death. Peter III of Aragon broke into the Templar treasury in Perpignan. In fact, the surprising fact is not that monarchs violated the Templar strongholds, but that the violations were so few in number given the temptations and the impecunious state of royal treasuries. The restraint exercised by monarchs over the century and a half of Templar ascendancy must be attributed to the moral force exerted by the Templars, as also the concern that a raid demonstrating naked greed would undermine their own standing with the church.

In 1307, Philip IV of France, motivated by the terrible financial state of his economy, and having already raised all the money he could through the traditional mediaeval sources of debasing the currency and seizing the property of the Lombards or the Jews, turned on the Templars. Philip began a propaganda campaign that aimed to strip the Templars of their moral standing. Templar leaders were arrested in a surprise raid and were accused of heresy, apostasy, devil worship, sexual perversion and a number of other sins against the mediaeval code of morality. ${ }^{\text {vi }}$ The Templar leaders confessed under torture, and even though they later recanted, they were found guilty and many were burnt at the stake.

The properties of the Templars were carefully inventoried, lands rented out, and the treasury taken over by royal officials. The Church, with no hope of expressing moral outrage, decided to join the predators. Pope Clement V abolished the order in 1312 and devoted his energies to securing some of its properties for other orders in the Church. Thus Philip succeeded in his aim of reducing the moral standing of the Templars, and seizing its assets. But despite his protestations otherwise, the act in more commercially minded countries such as Italy was seen as one of pure avarice. ${ }^{\text {viii }}$ 
The lesson from the demise of the Templars, which was repeated time and again, was that no agent, however powerful or sacrosanct, could protect wealth against a determined government. Interestingly, an important outcome of Philip IV's depredations was that the Church realized the threat monarchs represented to its own property. For this reason, it turned from accepting property as a necessary evil (after all, Jesus inveighed against riches) to stoutly defending it as an inalienable right. Clerical scholars started to argue that the state did not have rights over the property of its subjects, and secular scholars soon took this theme up, finding support for it in Roman Law. ${ }^{\text {ix }}$ Perhaps as a result, outright expropriation became more rare in Western Europe, and was generally targeted at infidels, such as Arabs or Jews.

Greed was not the only, nor even the most important, reason why governments coveted the wealth of their citizens. They were lead to expropriate their own citizens by their desperate needs for funds to finance their military efforts. In the long run, states could fund expenditure through taxes. But war brooked no delay. The alternative to confiscating citizens' wealth was to borrow -- an alternative a modern government knows all too well. But this led to a paradox. It is both costly and unpopular to levy taxes on the wider population so as to pay a few creditors. One reason a government would repay its debt even in the face of these costs is to keep the spigot of future financing open. But if it had the ability to persuade a few citizens to put up more when it was in need (what in mediaeval times was euphemistically called a forced loan), then it had little incentive to repay old loans. Since creditors, as a result, had no punitive power over the government, they had no reason to trust the government to repay. This then made it all the more certain that the government would renege on any debt contracted in good faith, and resort periodically to expropriation, disguised as forced loans or defaults. 
The easy targets (after the usual suspects like the Jews had been shaken down) were, of course, the rich, especially financiers. The manifest usurer was anathema to the Church, and hence accepted prey. Financiers were also likely to keep their wealth in a liquid, and conveniently removable form. This is an aspect that makes, even in modern days, financiers the likely target of government taxation or expropriation. In this the governments' logic essentially parallels that of the bank robber, Willy Sutton, who when asked why he robbed banks answered, "Because that is where the money is". In an atmosphere of forced loans and repeated defaults, finance, not surprisingly, did not flourish.

The resolution to this paradox was simple. The government had to find a way to make it more credible that it would repay. This would then make the route of borrowing and repayment via steady taxation more credible. The conventional wisdom is that the Venetian Republic, the Netherlands, and in the late seventeenth century, England, managed to devolve power to investors -- government in these countries was more representative of the rich investor than were the absolute monarchies that prevailed elsewhere. ${ }^{\mathrm{x}}$ This then made it hard for the government to default. The process by which the devolution of power took place is much more controversial. To understand why, consider England.

\section{The Transformation Of the English Monarchy}

The early Tudors, Henry VII and Henry VIII, were among the most rapacious and arbitrary monarchs. They had their way with all the institutions of governance that were meant to check their power - the aristocracy, the church, the parliament, and even the judiciary. Henry VII steadily expropriated the great lords whom he feared as threats to the throne. Henry VIII not only continued along his father's path but in one of the greatest land grabs in history, he dissolved the monasteries in England and took over their land, amounting by some estimates to over 30 
percent of the land holdings in England at that time. This, however, was not enough. In addition, the Tudors resorted to repeated "voluntary" loans from rich citizens. Consider the plight of one Richard Reed who did not contribute to one of Henry VIII's levies ${ }^{\mathrm{xi}}$ :

"The English army was then in the field on the Scots border. Reed was sent down to serve as a soldier on his own charge; and the general...received intimations to employ him on the hardest and most perilous duty, and subject him, when in garrison, to the greatest privations, that he might feel the smart of his folly and sturdy disobedience."

The Stuarts continued the practice of expropriation. As late as 1672, in the infamous Stop on the Exchequer, Charles II suspended debt payments to bankers amounting to about $\$ 1.3$ million pounds, at a time when annual Crown income was less than 2 million pounds. ${ }^{\text {xii }}$

Yet soon after, England had a constitutional monarchy. In the Glorious Revolution of 1688, the Stuart King, James II, was overthrown and replaced by William and Mary. The new monarchs agreed to a Declaration of Rights. The Crown recognized the legislative supremacy of Parliament and also the need for parliamentary consent for a standing army in peacetime. Furthermore, judges were protected from arbitrary dismissal, strengthening individual liberties and the property rights of the citizens against the Crown.

The consequences for the English government's ability to borrow were extraordinary. In 1688, government debt was about 1 million pounds, about 2 or 3 percent of GDP. Much of the debt was short term (recall that creditors lend only short term if uncertain of the motives of the debtor) requiring between 6 and 30 percent a year in interest, at a time when the Dutch government was able to borrow long term at 4 percent per year. ${ }^{\text {xiii }}$ By 1697 , government debt had multiplied 17 times to about 40 percent of GDP, a significant portion of which was long term. The proximate cause of the increase in government debt was war with France, but it also reflected the greater willingness of investors to supply the government with debt. Even while 
government debt mounted, interest rates came down, from 14 percent soon after the revolution to about 6 percent in 1697.

The now conventional explanation is that by constitutionally enhancing the "countervailing" power of Parliament and the judiciary, the Crown offered investors the credible commitment that it would not attempt to expropriate them. ${ }^{\text {xiv }}$ Parliament represented both the moneyed interests of merchants and financiers (the Whigs) and the landed gentry (the Tories). Given its composition, the increase in its power as a result of the curbs on the power of the king made property and financial contracts much more secure. In turn, investors obtained the confidence to invest. Thus, the argument goes, the internal constitutional limitations on the English Crown's powers allowed it to raise large sums at short notice, giving it external strength and transforming England into an European nation of the first rank. ${ }^{\mathrm{xv}}$

There is, however, something incomplete in the argument that the government could show its commitment to respect property by setting up a more democratic political process, which kept the arbitrary powers of the government in check. If it were so easy to offer a credible commitment, why did other governments, especially those of other nation states like France and Spain that were perpetually in financial need, not do so?

One possibility is that their situations were different. For instance, it could be argued England's government could be tamed more easily because it had no standing army to carry out its arbitrary orders, and finance for raising an army had to be approved by Parliament. Since many members of Parliament were also property owners, Parliament was unlikely to approve the raising of an army that could be used to expropriate the citizenry. By contrast, the French and Spanish kings had standing armies -- external threats were more proximate, and they did not have the luxury of time provided by a Channel separating them from their enemies. Thus, the 
argument must go, these monarchs could not set up credible internal constraints on the power of their governments, even though they too desperately lacked for finance.

Too much, however, could be made of these differences in geography. It is difficult to believe that the absence of a standing army in England was the primary reason for the English king to be better able to curb his own powers. After all, even if England, surrounded by seas, was not as exposed to sudden foreign attack as France or Spain, the English king did have a smaller standing police force to keep internal peace, and did use it to expropriate the citizenry. Or to see it another way, even if the constitution mandated that the king needed Parliament's permission to raise an army, he could simply have ignored constitutional niceties once he was allocated the funds and turned the army against Parliament. The loyalty of the army would then have depended on who could give it a better deal in the long run (After all, Ancient Rome too tried to keep popular generals and their armies far from the center of power, but eventually the Praetorian Guard chose many of the later Emperors). That the king did not, or could not, attempt to turn the army suggests other factors were at work

Put yet another way, the great lords who surrounded the feudal monarch had powerful armies. Yet constitutionally bound government, and respect for property, emerged only after the demise of feudalism. Why only then and not before? There seems something missing in the argument that governments became better able to borrow by setting up the checks and balances on themselves that would curb their own baser instincts. What was the power that bound them?

Perhaps it is more fruitful to question whether it is possible for any government to set up countervailing power, especially the kind set up through constitutions: An alternative view is that the interactions between powerful national players are rarely governed by constitutional rules since, at the national level, most rules can be changed. Political power is not easily conferred by 
legislative fiat or a change in the constitution. Instead, it has much deeper roots, some lying in the ownership of property itself. It is more fruitful to think of the devolution of political power and the security of property as intertwined processes in which secure property eventually became the fount of political power.

Pursuing this line of argument, Parliament did not become powerful in England as a result of constitutional changes brought about in the Glorious Revolution of 1688, it was already powerful as evidenced by its ability to depose two Stuart kings (Charles I and James II) in quick order. This then means that the constitutional changes largely reflected the power relationship that pre-existed these changes, while the conflict between the Stuarts and Parliament was only a last ditch stand by the king against an inevitable passing of the balance of power. Of course, constitutional change made the devolution more secure against reversal. Our point is that it was the culmination rather than the source of the transfer of power. Let us now explain.

\section{The Decline of the Aristocracy and the Rise of the Market}

A constitution is simply words on a piece of paper, and sometimes not even that.

Parliament commanded no armies directly. How did it gain more power over the monarchy than did the power feudal lords with their loyal retinues who surrounded the mediaeval monarch? To see why, we have to delve deeper into history. The first piece of the answer is the decline of the great lords.

Henry VII, the Lancaster pretender to the throne, defeated Richard III unexpectedly at Bosworth Field in 1485, thus ending the War of the Roses between the House of York and the House of Lancaster. Given Henry's questionable claim to the throne, he set about eliminating serious threats to it. One way was to directly attack the most powerful of the lords - and since power stemmed from land holdings, confiscate their land and sell it off in pieces so that no 
successor would pose a similar threat. Henry VIII continued this policy, executing among many others, the Duke of Buckingham, who was the highest and richest amongst the nobility. The Tudors also took care not to create any new concentrations of power: They created no new dukes during their reign. ${ }^{\mathrm{xvi}}$

While some of the most powerful lords were dealt with on trumped up charges, not all could be eliminated in this way. The source of a lord's coercive power came from his band of armed dependents. Since there was not much of a market for food or land, the surplus produced by a lord was used to feed a retinue of servants and marginal tenants. ${ }^{x v i}$ He offered them protection against other roaming bandits (or equivalently in those times, other lords), and rented out land to them at low rates. In return, they offered their loyalty and arms to the lord, wearing his livery as a sign of their allegiance. The lord used his armed band to intimidate courts, rivals, and even the King.

To deal with these armed bands, Henry VII passed a series of Acts asserting that the prime loyalty of every subject was to him, the king, and not to the subject's local lord. He forbade the employment of royal officials by others. And he started enforcing an old law restricting the use of livery to household servants, making examples of those lords who continued to maintain a personal militia.

In the meantime, there was another equally compelling reason for the lords to disband their militias. As the market for food expanded, the surpluses generated by the land could be sold instead of given to servants and tenants. Feeding the retinue was no longer free. And as rents for land increased, and a market for land sales started flourishing (more on this shortly), lords started feeling the true cost of maintaining inefficient but loyal tenants. The more efficient tenants also felt the cost of spending time in the service of the lord, rather than in the more profitable 
occupation of tilling their fields. They much preferred to pay a market rent in cash rather than paying a below-market rent and having further feudal obligations. Thus as markets expanded, non-market obligations like military service came under pressure, a phenomenon we will see again and again under many guises.

Moreover, long years of peace under the Tudors left the lord unable to use his militia to even fulfill his traditional feudal obligations to the king. As the costs of maintaining militias became more apparent and the benefits declined, some lords disbanded their militias. The process became self-reinforcing. Since one of the benefits of a militia was protection against the militia of other lords, fewer militias meant even fewer benefits. Thus, over time, lords lost their coercive power due to pressure from the monarchy and from economic forces. A 'Duke of Buckingham in the early sixteenth century, with his castles, his armories, and his hundreds of armed retainers', gave way to 'a Duke of Newcastle in the mid-eighteenth century, with his Palladian houses' and his political connections. ${ }^{\text {xviii }}$ The Tudors and the market they helped create had effectively crushed the coercive power of the aristocracy.

\section{The Rise of the Squirearchy}

What took the place of the aristocracy? The great confiscations by the early Tudors culminating in the dissolution of the monasteries brought a huge amount of land on the market. Some of this land was granted away, but much of it was sold, with great benefit to the Crown's coffers. Because they had a direct interest in the market value of the land, the English monarchs amended the law to give buyers better title to the land, allowing them to sell it further if necessary. The flourishing market for land had a number of effects in addition to what we noted earlier. First, the more prosperous farmers, the ones who generated substantial profits from their land, could buy more, while those who did poorly sold their land, or had it seized and sold by 
creditors. Second, farmers who had scattered strips could consolidate their land holdings and manage the consolidated land better. ${ }^{\text {xix }}$ Third, prosperous professional men like lawyers and merchants could buy land, the age-old symbol of status, and bring modern management techniques to it. ${ }^{\mathrm{xx}}$ Land moved into the hands of more able farmers and more competent managers.

The consequence was the emergence of an intermediate class between the lord and the peasant, the squirearchy (or alternatively, the gentry), which was more intimately involved with the land than the former and more apt to take risk with new techniques than the latter. The archetypical member ${ }^{\mathrm{xxi}}$

"was not tempted by great possessions into the somnolence of the rentier; was less loaded than most noble landowners with heavy overhead charges in the shape of great establishments; did his work for himself, instead of relying on a cumbrous machine to do it for him; owned, in short, his property, instead of being owned by it."

He was thus much more able to exploit the land he farmed, and much more closely linked to it, than either peasant or lord. When landholdings were vast, the skills required to manage that land and generate revenues were supervisory skills - the feudal lord employed overseers who supervised a steep hierarchy at the bottom of which was the peasant. While the peasant had the capacity to get to know the land well and get the most productive value from it, without ownership he had little incentive or ability to do so. In fact, in the early Middle Ages in England, and till quite late in other countries, serfs were not allowed to own property, had to pass on their earnings to their master, and were bought and sold with the land they tilled. ${ }^{x x i i}$ Moreover, to reduce the need for management, the individual peasant often had "no choice of date or of crop; he must plough and reap with the rest, and sow the same seed as they."xxiii 
While the great lord probably was tutored since early childhood to drive overseers and supervise his estate, he did not have an intimate relationship with the land - it was too vast for any one man to get to know well. Management was often simply the maintenance of tradition, which few lords transcended. As a result, the revenues generated from the land did not really depend on whether this particular lord owned it, or whether some other person, who was equally capable of driving overseers and sticking with custom, owned it. In economic parlance, the income from the land to the lord was a pure rent - it derived simply from his ownership of the land, and there was little other economic link between the property and the owner.

Not only was property loosely linked to the lord, the extent of security of property would have made little difference to the size of the revenues generated. Since the peasant exerting the effort did not own the land, and farmed it at the pleasure of the lord, greater security for the lord's ownership did little for the peasant. Of course, the lord may have had some additional incentive to make improvements to the land if he knew his tenure was secure, but given the kind of extensive agriculture he practiced, these would not have added substantially to revenues.

Given all this, the lord owned his extensive holdings only because he had a sufficient armed force to bloody the monarch's nose. If the monarch did not fear questions about his own legitimacy when he expropriated other inherited land, if he did not fear that other lords would band together against him, and if the resistance this lord could pose to an assault was limited because his band had withered away, property could, and would, change hands whenever the monarch desired it. The inefficient structure of ownership was itself the cause for the insecurity of property. From the perspective of the monarch, one lord was just as good as another, because each one's supervisory skills allowed them to generate approximately the same surplus for 
taxation. The only security to property was then the favor of the sovereign. Property could simply not be secure when the owner was so replaceable.

The gentleman farmer, owning smaller (but not economically unviable) plots was different. First, the very origins of his land, typically acquired through purchase using his own accumulated wealth rather than through inheritance or custom, indicated he had a competency that was required neither of lord nor of peasant. Second, on land he farmed himself, he was likely to make the decisions on what to plant and where, experiment with different crop rotation and irrigation techniques, understand how the weather mattered every season and which clump of trees provided beneficial shade and so on. Both because he was competent and because he was closely involved in managing his land, the gentleman farmer was very effective in exploiting the land he farmed. In addition, he would also be more able to rent land out well, since his intimate knowledge of the land's possibilities would allow him to pick appropriate tenants.

In short, the burgeoning market for land moved land to the highest value user, the competent gentleman farmer. And as he became more familiar with it, his ability to generate value only increased so that he was, given the circumstances of the times, far and away the most economically efficient owner of the land. Unlike the great lord, the intrinsic value of the land he owned would be far less if the gentleman farmer were expropriated for his skills would then be unavailable to manage it. It would be better for a far-sighted government to negotiate a steady tax from each of these farmers than to expropriate any one of them. In addition, security of property would enhance the taxes the gentleman farmer would pay because he would then have a greater incentive to invest in the land and create value.

While these economic concerns may not have been foremost in the Tudor monarch's mind, the great lords were. In a further attempt to undercut the power of the lords, the monarchy 
devolved more and more of the duties of tax collection and dispensing local justice to the gentry. ${ }^{\mathrm{xxiv}}$ But this then made the gentry indispensable to the monarch $^{\mathrm{xxv}}$ :

"The plain truth was the law, as they [the gentry] practiced and understood it, and the local administration of England, had made the ordinary life of the country depend at every point on them, and hardly at all upon the Crown. The entire machine - law courts, parishes, poor law, city and country - could run very well without the king; but it could not run without the gentry. In other words, the gentry was essential to the power of the king, but he was not essential to theirs."

In short, even while the gentry were becoming economically more powerful, they were also becoming critical to land administration. From the perspective of the overall productivity of the agricultural sector, this was probably a good thing for their administrative indispensability enhanced their sense of security in their property, which undoubtedly made them more productive, and further reinforced the security of their property.

The rise of the squirearchy was a steady process. By one count, there were 1,000 esquires in Henry VIII's time, and this number had expanded to 16,000 by Elizabeth's time (though there is a certain latitude in who precisely qualifies as an esquire). There is no doubting the fact that the steady rise in productivity of English agriculture dates from the time of the emergence of the gentry. Early historians thought it uncontroversial that the emerging gentry were much more productive than the lords and peasants they displaced. ${ }^{\text {xxi }}$ Since then, ideology has embroiled the debate on who exactly was responsible for the increase in productivity, though there have been recent attempts to use large sample data to extricate the facts from controversy. ${ }^{\text {xxvii }}$ The data suggest the emerging gentry in the $16^{\text {th }}$ and $17^{\text {th }}$ century did contribute substantially to the productivity revolution. ${ }^{\text {xxviii }}$ The wealth of the gentry expanded in tandem. By 1600, it was rumored that the gentry were three times richer than the church, nobility and rich peasantry put together. ${ }^{\text {xix }}$ 
So the decline of the aristocracy was accompanied by the rise of the squirearchy. We will argue that the squirearchy was more able to curb the power of the monarchy than were the great lords. How did this happen? After all, the squires were individually less powerful, and collectively more dispersed than the great lords. What bound them together against the king?

\section{Parliament and the Origins of Property}

Large, dispersed, groups have a harder time coordinating actions than narrow focused ones, a point we will come back to in later chapters. Despite being numerous and dispersed, significant portions of the gentry could come together. The origins of their property gave the gentry a common interest in defending it, while Parliament provided the common meeting ground where their actions could be coordinated. The gentry were thus able to overcome the impediments to collective action that typically plague large groups. Let us explain in greater detail.

In dissolving the monasteries, Henry VIII was taking on the might of Rome. Opposing forces could well question the legitimacy of his reign, and could threaten it if given the appropriate backing of the Holy Church. He needed allies, and he found them by distributing church lands to the gentry so that "being bound by the same ties of private interest, they might always oppose any return to the dominion of Rome." ${ }^{\text {xxx }}$ In the words of a British historian, ${ }^{\text {xxxi }}$ "the participation of so many persons in the spoils of ecclesiastical property... was of no slight advantage to our civil constitution, strengthening, and, as it were, infusing new blood into the territorial aristocracy, who were to withstand the enormous prerogative of the crown. For if it be true, as surely it is, that wealth is power, the distribution of so large a portion of the kingdom... must have sensibly affected their weight in the balance. Those families... which are now deemed the most considerable, will be found, with no great exception...to have acquired no small portion of [their estates]...from monastic or other ecclesiastical foundations."

In consolidating opposition against Rome to protect their own position, therefore, the Tudors also consolidated opposition to future kings. Many amongst the gentry were especially wary of 
monarchs who had Catholic leanings, or who sought ties with other Catholic monarchs. ${ }^{\text {xxii }}$ The troubles faced by King Charles I (executed) and James II (deposed) were in no small part, due to this.

Parliament provided the coordination the dispersed gentry needed to assert its recently acquired economic power. Parliament, historically, had been the institution whose consent the King needed to impose new taxes. It was the mechanism by which the King negotiated with his principal sources of taxes, and it was not easily dispensed with, especially once the king came to rely on the squirearchy to collect his taxes. This does not immediately mean that Parliament could stand up to the monarch. The early Tudors exerted almost absolute dominion over Parliament. ${ }^{\text {xxxiii }}$ Elizabeth only had to pass the word to Parliament not to discuss a subject for them to desist. Her chancellor, on confirming a new speaker of the House of Commons, warned him against the House of Commons meddling in any thing touching on 'her majesty's person or estate, or church government. ${ }^{\text {xxxiv }}$ His warning was obeyed scrupulously.

But as the gentry grew in wealth and power, and as they saw signs of revival of Catholicism, their opposition strengthened. Parliament had already become fractious towards the end of Elizabeth's reign, complaining vociferously about the creation and sale of monopolies over such essentials as salt. By the time of her successor, James I, Parliament was actively voting down the King's proposals and standing up for the right to free speech and the liberties of its members. James vainly threatened his Parliament, "I am a man of flesh and blood, and have my passions and affections as other men; I pray you do not go too far to move me to do that which my power may tempt me unto."xxxv But Parliament ignored him.

A simple economic calculus would explain why Parliament had become so confident. Suppose matters came to a head between the King and the Parliament about property or, 
equivalently, taxes. While honor and custom would sway a few, many citizens, especially those who were being recruited to fight, would decide on the basis of their pocket. The newly recruited militias would give their loyalty to those that would pay them regularly and well: As the saying goes, pecunia nervus belli or money is the sinews of power. The King could promise to declare his opponents traitors, seize their lands, and use the proceeds as well as his own wealth to pay those who sided with him. Parliament could promise to do the same thing in reverse. So the side that would attract the greater following would be the side that could promise the militia greater wealth, both of its own and from seizing its opponents.

For reasons discussed earlier, the gentry were especially good at managing and generating wealth from their land. The King and the great lords had no such ties to their land. Far less would be lost if the King and the great lords were relieved of their holdings and the gentry retained theirs, than if the reverse happened. So the gentry clearly had the ability to promise militias more. There were, of course, other factors that added to their ability to attract a following. Much of the land tax collection machinery was in the hands of the gentry, so they were better prepared to fund the war while it was in progress. Furthermore, they were men with strong ties to the local population while the King and lords were remote. The fundamental point, however, is that the balance of power had changed. If the monarchy were not far-sighted enough to see this, it might indeed take a Civil War, a beheading, and a revolution to convince the monarchy that power had indeed shifted hands! Certainly, there were men in the midst of these revolutionary times who saw that matters had changed. Thus Henry Neville, a member of parliament, exclaimed to the House of Commons in $1658^{\mathrm{xxxvi}}$

"The Commons, till Henry VII, never exercised a negative vote. All depended on the Lords. In that time it would have been hard to have found in this house so many gentlemen of estates. The gentry do not now depend on the peerage. The balance is in the gentry. They have all the lands." 
As an elected Parliament gained power over the monarch, the conditions for a constitutionally limited government were finally in place. ${ }^{\text {xxxii }}$ The Glorious Revolution formalized this state of affairs, and enshrined the concept that taxation could not be arbitrary, and required the consent of the peoples' representatives. Less than a century later, this principle was reiterated in the American Declaration of Independence.

\section{A Summary}

Let us recapitulate. There were three critical steps on the way to limited government. The first was the decline of the coercive power of the great nobles. This ensured that raw physical might no longer determined economic outcomes, and that ownership was not the prerogative of an inefficient few. The second was emergence of an intermediate class, the gentry, who were not just economically powerful as a class, but also efficient exploiters of the land they owned. The third was the existence of Parliament as a coordinating institution. Without it, the dispersed gentry would have struggled to assert its new economic power. Thus, the Parliament, weak in the Tudor years when the gentry was emerging, became strong when the gentry became wealthy. The power of the Parliament was also strengthened by the commonality of interests among the gentry. Most derived income from land and many owned land that was previously expropriated from the Catholic Church.

Thus the emergence of property rights in England was due to a fortuitous combination of factors. Were all of these factors necessary? James Harrington, an Englishman who was a contemporary of Oliver Cromwell, and studied the sources of power in his 1656 book, Oceana, believed the redistribution of land through the great Tudor expropriations (and the land sales by Stuart monarchs as they attempted to fund their extravagances) was solely what changed the balance of power. This belief in property as the fount of power - because those who have 
property have the ability to pay armies -- is clearly enunciated in one of Harrington's pamphlets $^{\text {xxxviii }}$

All government is founded upon overbalance in propriety. [i.e., governmental power derives from property; the man or men whose property exceeds (overbalances) the total wealth of others in the state controls its government]

If one man hold the overbalance unto [over] the whole people in propriety, his propriety causeth absolute monarchy.

If the few hold the overbalance unto the whole people in propriety, their propriety causes aristocracy or mixed monarchy.

If the whole people be neither overbalanced by the propriety of one, nor of a few, the propriety of the people (or of the many) causeth the democracy or popular government.

There is a long tradition for the belief that widely distributed property leads to democracy and civil society. Some societies have suggested maximum limits on what can be owned while others have suggested minimum limits: The Roman Republic had an 'agrarian law' that limited the land any one person could own. Jefferson's draft constitution for Virginia, written in 1776, required that each adult have 50 acres of land. ${ }^{\text {xxix }}$ Yet the argument that property is power is, at some level, circular. To claim that property leads to power is to presuppose that the government respects allocations of property. Else why could the government - which enforces property rights -- simply not declare the property rights of the rebels null and void if it feels that they would fund armies against the government?

If we were to stress a single most important factor in the emergence of property rights, it would not just be the wider distribution of property but also the economic (or social) ties between the property and the owner, which is all that would persist in an atmosphere of anarchy. Thus Harrington omits a vital step in his arguments: The sale of seized land and the flourishing 
subsequent land market led to property being held by those who could manage it much better. It was this - the economically efficient holding of property -- that enhanced the security of property, because the efficient holders had the economic power to defend their property against others. In addition, of course, the ability for the gentry to coordinate action through Parliament helped convert their dispersed, but substantial, economic power into political power.

Would it have been enough to open a market for land? Was the expropriation of the great lords and the monasteries necessary for the wider distribution of power? While it is hard to answer such counterfactual questions categorically, we believe the expropriations, despite violating property rights, somewhat paradoxically helped build future limitations on the monarchy. For one, the expropriations did redistribute wealth directly spreading economic power. More important, the lords and monasteries owned a significant portion of the land in their localities. They were local monopolists. Even if smaller properties were more efficiently managed, like all monopolists they may have preferred holding on to their land, managing it inefficiently, but squeezing monopoly profits out of the local populace. Thus a market for land may not have moved land into more efficient hands, were it not for the expropriations, which were a sort of anti-trust action.

Our argument suggests why government was much more participatory in the cities than in the nation states. In the city-states, the dominant source of wealth was not land but trade and manufacture. The surplus generated by these activities was clearly closely tied to the expertise, incentives, and relationships of the owner of the business, much as land was tied to the commercial farmer. It made economic sense to respect property rights within the city and to give citizens (a word that originates from the French cite and was originally applicable only to 
residents of a city) the sense of security by allowing them to participate in government. As the old saying goes "Stadtluft macht frei" or "City air makes free".

Clearly, the cities grew along with business, and there is no reason to believe that respect for property was highly developed in the early life of a city. But over time, the quantum of business grew and businessmen demanded, and obtained, respect for property, as well as participation in city government.

In the nation states, by contrast, the dominant source of revenue was land. So long as property holdings were concentrated, the nation state could not commit to respect property. Even if manufacture or trade started up, it would be hard for the nation state to show respect for business property when business output formed only a small fraction of total output. Thus it was only after the breakup of the feudal estates or after extensive land reforms that the group of gentry emerged who not only were strong advocates of the institution of private property, but also forced government to respect it. This then paved the way for competitive industry to emerge. Of course, once industry became sufficiently important, the pattern of land holdings might become less important to the security of property.

English history offers some evidence of this sequence. One of the rights the king attempted to usurp for himself as industries grew was the right to grant industrial monopolies. Consider the following case, which vividly demonstrates that these monopolies contributed to the insecurity of property, the arbitrary power of the king, and the ruin of economic activity. In 1614 , a scheme was concocted to ${ }^{\mathrm{xl}}$

"take from the Merchant Adventurers [a trading company] their rights to export unfinished woolen cloth to the Netherlands and to give to a new company the exclusive right to export cloth... It was estimated that the export of entirely finished cloth... would bring in an additional profit of 600,000 to 700,000 pounds a year to those engaged in the cloth trade. Of this the king was to have 300,000 pounds for his grant of the franchise to the new company. The Dutch... refused [to let in] the English finished cloth, and the new company came to a quick end. 
Yet before the Merchant Adventurers could recover their old rights, which they did at a cost of between 60,000 and 70,000 in bribes to James' officials, the entire cloth trade had been disorganized...As late as 1620 the English merchants were exporting only half as much cloth as they had sent abroad in 1613."

Parliament saw the danger to the security of property (and its own power) from these monopolies, and in 1624, passed the Statute of Monopolies, which forbade the issuance by the king of patents of monopoly to individuals except in the case of new inventions. The antimonarch Parliament that served between 1640 and 1660 went further, and virtually ended the practice of granting monopolies to corporations, as well as individuals. ${ }^{x l i}$ So in addition to protecting the rights of land owners, the power of the landed gentry acting through Parliament placed constraints on the arbitrary powers of the king over industry.

Eventually, of course, industry became the source of security to property. Even though the landed gentry were instrumental in breaking the power of the monarchy, eventually they used Parliament to further their own interests. The emergence of small and medium sized farmers in the $16^{\text {th }}$ and $17^{\text {th }}$ century - the Yeoman revolution - gave way to Parliamentary enclosures and the Landlord revolution in the $18^{\text {th }}$ and $19^{\text {th }}$ century. While the former movement was progressive and enhanced productivity, the latter redistributed wealth to the newly politically powerful. ${ }^{\text {xlii }}$ But industry had come into its own -- as evidenced by the battle over tariffs on food that it eventually won - and power shifted to new defenders of property.

\section{Other Countries}

We have focused on England because it is the canonical example of the emergence of constitutionally limited government. It is useful to see briefly whether other countries that developed constitutional government fit the mold. 
France is often the canonical counter to Britain. Historians have puzzled over why France did not achieve constitutionally limited government until the $19^{\text {th }}$ century. One reason is simply that the nobility and the church in France were all too strong before the French Revolution. Even a powerful king like Louis XIV only played the grandees off, one against the other. When he died they regained their power. ${ }^{\text {xliii }}$ Since French kings could not suppress the great lords, they tried to enlist the peasantry's support by protecting their property rights against encroachment by the lords. ${ }^{\text {xliv }}$ So the peasantry in France held a substantial portion of the land, but in small, relatively inefficient holdings. ${ }^{\text {xlv }}$ Land sales also did not take off, in part because the king had no incentive to make alienation easy for that would allow the peasants to sell out to, or be dispossessed by, the lords, and in part because, unlike England, there was no initial grand sale of expropriated land to jump-start the land market. So the gentry did not emerge as a class. Finally, since the king levied and collected taxes through a centralized bureaucracy directly from the peasants, he really had no need to summon any form of Parliament on a regular basis.

The French Revolution and the confiscation and sale of the properties of the church and the aristocracy had some of the effect in France that the Tudor expropriations had in England. It reduced the land and power of the nobility, strengthened the then miniscule French gentry as well as the rich peasant farmer, created a national market for land and food by abolishing internal impediments to trade, and created a more permanent institutional structure for representative government. As a consequence, the productivity of French agriculture increased substantially in the nineteenth century. ${ }^{x l v i}$ The political and economic effects of these changes were undoubtedly critical in fostering the late, but substantial, French industrial revolution.

If our arguments hold generally, then they should not be valid just historically but also more recently. Very crudely, our arguments suggest that in predominantly agricultural countries, 
the security of property - clear laws facilitating the ownership of property and its sale as well as a judiciary and a government that respects them and enforces rights -- should be low where land ownership is highly concentrated. Not only do big landowners have the ability to defend their property through private armies or through their influence over the local apparatus of the state, they have no incentive to see the infrastructure of a free market emerge to challenge their power. ${ }^{\text {xlvii }}$

This leads us to a final question. If wider (but not too wide) distribution of land led to participatory politics and respect for private property, why did every country not undertake land reform? Why till 1861 were the vast majority of Russians serfs, tied to the land and without protection from their overlords, and from the government? Why did it take the French Revolution, the Napoleonic conquests, and the revolutions of 1830 and 1848 for land to be distributed in Continental Europe in a way more conducive to intensive commercial farming and greater respect for property rights?

One reason may be the nature of the land in some countries. Some lands lend themselves to intensive farming, while others lend themselves to a mode of agriculture such as plantations that is more extensive. This may partly explain why Costa Rica has had a more democratic history than Columbia. The effects of the initial distribution of land may persist long after the distribution is no longer optimal as we noted in the introduction to the book. For example, even after the emancipation of indentured or slave labor reduced the profitability of the large Latin American haciendas, the owners did not disband them. The need to maintain a ready pool of unskilled, poorly educated, labor may explain why many of these hacienda-dominated countries did not pursue universal education and economic and social rights as vigorously as others did. ${ }^{\text {xlviii }}$ 
The argument that the necessary technology of production does not permit an ownership pattern favorable to the emergence of strong property rights applies not only to land but also to industry. When industry consists of large monopolies, which exist only because the government affords them privileges, the government is likely to have little respect for property. For example, firms in extractive industries have value largely because of their rights to extract, and really do not utilize huge amounts of human ingenuity. In countries that are abundant in natural resources - such as Zaire - the government can extract large amounts of money simply by withdrawing a mining privilege from one company and auctioning it off to another. Of course, eventually bidders realize they will have to factor in the cost of future bribes that will be needed to keep their privileges. The outcome, however, is that the government will have little incentive to respect property rights. Only a few countries have overcome the curse of being richly endowed with mineral resources.

But the most important reason for why countries did not attain the appropriate distribution by design may be that the self-interest of the government and the nobility did not permit land reform, even if it would benefit the country as a whole. Certainly, an individual lord could not hope to gain by dividing up his land and selling the pieces to the peasants who farmed it. If other lords did not follow suit and force an eventual change in the climate of property rights enforcement, our revolutionary lord would find that the peasants he had sold land to enjoyed even less security of tenure now that the lord was not present to protect them. Moreover, any wealth the lord gained from sale would itself be up for grabs, now that he could not hold out the prize of grain or below-market-rents to enlist the support of his peasants in battle. .lix $^{\text {. }}$

The sovereign might also not have had the incentive to move to distribute land widely. After all, even if property rights became more secure, and the land became more productive, he 
would lose power. In many cases, it would be in the monarch's self interest to continue coerciveextractive policies, even if detrimental in the long run for the country -- as Louis XV is famously supposed to have said, "France will last my time."

If initial distributions of land holdings tend to persist in the absence of forcible reform, the legacy of history may explain why some countries, or even parts thereof were lucky, while others not. For example, Northern Italy and Southern Italy are extremely different in their economies, Northern Italy being much more progressive than Southern Italy. Estates were much larger in the South and the peasants far poorer. A number of historical factors including the Norman conquest of the South in the eleventh century and the greater devastation caused by the plague in Southern Italy in the fourteenth century could account for the differences in land distribution. ${ }^{1}$ In turn, these differences may partly explain the disparity in economic progress between the North and the South that persists even today.

The legacy of historic land distribution patterns seems to be important in India. Areas in which property rights over land were given over to large landlords by the British in colonial times have significantly lower agricultural investment, lower agricultural productivity, lower rates of literacy, and higher rates of infant mortality in recent years. ${ }^{\text {li }}$ The growing disparity between the booming West and South of India and the relatively stagnant Central and Northeast areas is probably, in some measure, a legacy of history.

Similarly, some former colonies of European powers developed stronger respect for property rights earlier than others: The initial European settlers migrated en masse to a colony if the climate was hospitable and the land disease-free - leading to the emergence of a group of yeoman farmers who formed a solid base for representative, constitutionally bound government. By contrast, land holdings in a colony were much more concentrated, and industry much more 
extractive, if the land was inhospitable so that only the minimum number of Europeans migrated to oversee large holdings worked by native labor. ${ }^{\text {lii }}$ These latter countries would have had to await the emergence of a viable manufacturing and trading class to establish secure property rights, but the emergence of that class would itself be held back by the absence of property rights and finance.

Finally, some governments care more about their own power than the prosperity of their citizens, giving us examples of the consequences of inappropriate redistributions of property. Fearful of their role in supporting the institution of private property, Stalin exterminated the yeoman farmers in Russia, the Kulaks, in the 1920s and 1930s and gathered their land into large collective farms. The collectivization of Russian land caused enormous losses in agricultural production - but served the intent of removing the yeomanry, a strong force for private property completely from the Russian landscape. Government could move ahead with communism unopposed.

More recently, formerly socialist economies have attempted to figure out how to distribute state owned property to private citizens so as to ensure a smooth transition to capitalism. Some economists have argued that it does not really matter who owns the property, all that matters is that property finds its way into private hands. ${ }^{\text {liii }}$ Our arguments suggest otherwise. Property in the wrong hands, especially if concentrated, can be very detrimental both to reducing the power of the state and to the emergence of free markets. The Russian Republic provides one clear illustration. In an underhand deal to win support for the 1996 Presidential election, Boris Yeltsin agreed to give a few powerful operators some of the best Russian companies at bargain basement prices. This was just the most egregious of events by which Russian industry and finance became dominated by a few, whose primary competence was 
contacts rather than business acumen. It is little wonder that these "businessmen" came to be known as oligarchs, reminiscent of the reactionary feudal lords that stood in the way of capitalism.

Not only do these oligarchs oppose the development of free markets and free access to finance, they also offer little countervailing force to a powerful state. Since their empires are not built on competence, they can be taken away as easily as they were acquired. The government of Vladimir Putin has, in fact, cut some of these oligarchs down to size and assumed significant power. Whether the oligarchs are replaced by others in a game of merry-go-round, or whether the oligarchs are done away with so that a truly competent and competitive business class emerges is a matter to be seen. In that lies the future of Russian democracy and free market enterprise in that country.

\section{Conclusion}

Historically, the greatest obstacle to the development of free markets, especially free financial markets, was the rapacity of governments. We have argued that the emergence of a class in England that individually was large enough to farm commercially and take risks, but was not individually strong enough to protect itself, created the demand for a constitutionally limited state. Institutions like Parliament and the administrative machinery served to coordinate this class and give it political power, which then resulted in the limitations on government it sought.

These safeguards were extremely important to ease the path of government finance.

Unlike with land or industrial assets, most financial assets are held passively - the holder has no great expertise in generating value from those assets. Since the government suffers only a loss of reputation if it expropriates the cash or gold held by its citizens, or if it repudiates the debt it owes them, the holders of financial assets are the first to be targeted by a government in need. It 
is rare that a troubled modern government takes the land farmers own, or the machines firms have, to pay its bills, but it is perfectly willing to pay public creditors only a fraction of the amount it owes. Finance therefore has to come within the perimeter of defenses built against the government by other forms of property for it to flourish.

But when investors feel safe, a country can benefit greatly because it can borrow to fund national enterprise, and not be limited by what it can raise in the short run through taxes. As historian Richard Ehrenberg, writing in the early part of the twentieth century, puts it, "England would not have been the Great Britain of today, it would not have conquered half the world, if it had not incurred a national debt of 900,000,000 pounds between 1693 and 1815." liv

\footnotetext{
${ }^{\mathrm{i}}$ See D. North and B. Weingast, 1989, "Constitutions and Commitment: The Evolution of Institutional Governing Public Choice in Seventeenth-Century England", The Journal of Economic History, 49, Issue 4: 803-832.

ii This is reminiscent of Gary Becker's argument (Gary Becker, 1983, "A Theory of Competition Among Pressure Groups for Political Influence" Quarterly Journal of Finance, 98, Issue 3: 371-400) that economically inefficient policies tend to lose out when in competition with more efficient policies. Our point is that economically efficient owners will be better able to command power than inefficient ones, provided they can come to the fore. Through much of the feudal period, they were not able to do so because of their lack of organization, the suppression of markets and the primacy of coercive power.

iii Weatherford, Jack. The History of Money: From Sandstone to Cyberspace. New York: Crown Publishers, 1997; 65.

${ }^{\text {iv }}$ Barber, Malcolm. The New Knighthood: A History of the Order of the Temple. London: Cambridge University Press, 1994; 268.

${ }^{\mathrm{v}}$ Barber, p266, see above.

${ }^{v i}$ Barber, p270, see above.

${ }^{\text {vii }}$ Weatherford, p69, see above.

viii Barber, p298, see above.

ix Pipes, Richard. Property and Freedom. New York: Alfred A. Knopf Publishers, 1999; 17-18.

${ }^{\mathrm{x}}$ See D. North and B. Weingast, 1989, "Constitutions and Commitment: The Evolution of Institutional Governing Public Choice in Seventeenth-Century England", The Journal of Economic History, 49, Issue 4: 803-832.

${ }^{x i}$ Henry Hallam. Constitutional History of England. New York: Harper and Brothers Publishers, 1876, p. 26.

${ }^{x i i}$ Carruthers, Bruce. City of Capital: Politics and Markets in the English Financial Revolution. Princeton University Press: 1996; 122.

xiii p. $822-824$, D. North and B. Weingast, 1989, "Constitutions and Commitment: The Evolution of Institutional Governing Public Choice in Seventeenth-Century England", The Journal of Economic History, 49, Issue 4: 803832.

${ }^{\text {xiv }}$ See D. North and B. Weingast, 1989, "Constitutions and Commitment: The Evolution of Institutional Governing Public Choice in Seventeenth-Century England", The Journal of Economic History, 49, Issue 4: 803-832.

${ }^{\mathrm{xv}}$ See Carruthers, Bruce. City of Capital: Politics and Markets in the English Financial Revolution. Princeton University Press: 1996; 122 for a development of this argument, see above.

${ }^{x v i}$ Finer, S. E. The History of Government III. London: Oxford Press, 1997; 1271.

${ }^{x v i i}$ See H. Pirenne. Economic and Social History of Mediaeval Europe. New York: Harcourt, Brace and World, Inc., 1937; 63.

xviii Lawrence Stone, Crisis of the Aristocracy. Oxford, 1956: 97.
} 
${ }^{x i x}$ Clay, C.G.A. Economic Expansion and Social Change: England 1500-1700. Cambridge: Cambridge University Press, $1984 ; 70$.

${ }^{x x}$ Clay, p. 83, see above.

${ }^{x x i}$ For the greater readiness to use new knowledge by the gentry, see for example, H.J. Habakkuk, 1987. "The Market for Monastic Property, 1539-1603" Economic History Review, 10, Issue 3: 362-380, and Clay, 1984, see above. The passage is from Tawney, p. 16, 1949, see below.

xxii G.G. Coulton, "The Mediaeval Village" Cambridge: Cambridge University Press, 1925, p. 13.

xxiii Coulton, "The Mediaeval Village", p. 39.

xxiv Stone, p121, see above.

${ }^{\mathrm{xxv}}$ Finer, $\mathrm{p} 1338$, see above.

${ }^{x x v i}$ Many of these historians drew from the investigations of Arthur Young. See the references in Robert Allen, Enclosure and the Yeoman: The Agricultural Development of the South Midlands, 1450-1850. Oxford: Clarendon Press, 1992, for a list of his works.

xxvii See Allen (1991) for a cogent analysis, see above.

xxviii See Gregory Clark, "Yields per Acre in English Agriculture, 1250-1860: Evidence from labor inputs", Economic History Review (1991), 44, 445-460 for a time path of productivity increases, and Allen (1991) Enclosure and the Yeoman, see above, for the controversies surrounding it.

${ }^{x x i x}$ R.H. Tawney. "The Rise of the Gentry, 1558-1640" The Economic History Review, XI: 5, and Stone, 1965, p. 75 , see above.

${ }^{\mathrm{xxx}}$ Hallam, p. 55, see above.

${ }^{x x x i}$ Hallam, p. 55, see above.

xxxii See, for example, Hallam, p. 36-37, see above.

xxxiii Hallam, p. 35 , p. 38 , see above.

xxxiv Hallam, p. 151, see above.

${ }^{x x x v}$ Hallam, see above.

xxxvi Pipes, p. 33, see above.

xxxvii We are being very imprecise about what part of the landed gentry opposed the monarchy. Certainly, the opposition to Charles I was concentrated amongst the lower gentry. But it also included elements of the nobility and the upper gentry.

xxxviii Negley and Patrick, The Quest for Utopia: An Anthology of Imaginary Societies. New York: Henry Schuman, 1952: 383.

${ }^{\text {xxxix }}$ Allen, p. 305-306, see above.

${ }^{\mathrm{xl}}$ Dietz, Fredrick. An Economic History of England. New York: Henry Holt and Company, 1942; 263.

xli Dietz, p. 267, see above.

xlii See Allen, 1991, see above.

xliii Finer, p. 1325, see above.

xliv Robert Brenner, "Agrarian Class Structure and Economic Development", in The Brenner Debate, ed. by. T. H. Aston and C. H. E. Philipin. Cambridge: Cambridge University Press, 1985.

${ }^{\mathrm{xlv}}$ p. 240, Patrick Karl O’Brien, "Path Dependency, or why Britain became an industrialized and urbanized economy long before France", Economic History Review, 1996, vol. 49, 213-249.

${ }^{x l v i}$ Peter McPhee, 1989, "The French Revolution, Peasants, and Capitalism", American Historical Review, 94: 1265-1280.

xlvii See R. Rajan and L. Zingales, "Which Capitalism? Lessons from the East Asian Crisis" Journal of Applied Corporate Finance, 11: 40-48, for an early statement of this point in a different context.

xlviii See Engerman, Stanley L. and Kenneth Sokoloff, 2000, "Institutions, Factors Endowment, and Path of Development in the New World", Journal of Economic Perspective, 3: 217-232.

xlix In an atmosphere where property rights are not enforced, it is better for a skilled lord to let the wealth be "buried" in the ground, and draw it out at regular intervals to pay his peasants, than to convert it into cash and see them take it away.

${ }^{1}$ John P. Powelson. The Story of Land: A World History of Land Tenure and Agrarian Reform. Cambridge: The Lincoln Institute of Land Policy, 1988, p. 89.

${ }^{\mathrm{li}}$ See Abhijit Banerjee and Lakshmi Iyer, "History, Institutions and Economic Performance: The Legacy of Colonial Land Tenure Systems in India", Working Paper, M.I.T., 2002. 
lii See D. Acemoglu, S. Johnson, and J. Robinson 2001, "The Colonial Origins of Comparative Development: An Empirical Study" American Economic Review 91: 1369-1401 for a theory of development based on the pattern of settlement.

liii See for example Maxim Boycko, Andrei Shleifer and Vishny. Privatizing Russia. Cambridge: Massachusetts Institute of Technology, 1995. Hindsight is always 20/20. In all fairness, given there was little in the way of an entrepreneurial class, those who reformed Russia had very little to work with, and not much of guidance from past work. Many of the recent advances in Institutional Economics have come from those who learnt from their Russian experiences.

liv Capital and Finance in the Age of the Renaissance: A Study of the Fuggers and their Connections by Richard Ehrenberg, 1928 Harcourt, New York. 